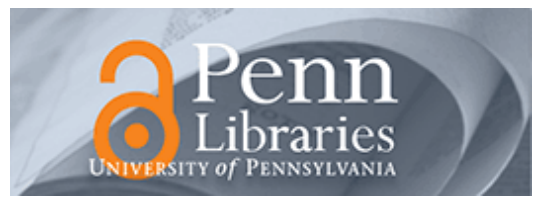

University of Pennsylvania

ScholarlyCommons

$12-1998$

\title{
Language Policy, Language Education, Language Rights: Indigenous, Immigrant, and International Perspectives
}

Nancy H. Hornberger

University of Pennsylvania, nancyh@gse.upenn.edu

Follow this and additional works at: https://repository.upenn.edu/gse_pubs

Part of the Education Commons, Linguistics Commons, and the Other Languages, Societies, and Cultures Commons

\section{Recommended Citation}

Hornberger, N. H. (1998). Language Policy, Language Education, Language Rights: Indigenous, Immigrant, and International Perspectives. Language in Society, 27 (4), 439-458. http://dx.doi.org/10.1017/ S0047404500020182

This paper is posted at ScholarlyCommons. https://repository.upenn.edu/gse_pubs/262

For more information, please contact repository@pobox.upenn.edu. 


\title{
Language Policy, Language Education, Language Rights: Indigenous, Immigrant, and International Perspectives
}

\begin{abstract}
Indigenous languages are under siege, not only in the US but around the world - in danger of disappearing because they are not being transmitted to the next generation. Immigrants and their languages worldwide are similarly subjected to seemingly irresistible social, political, and economic pressures. This article discusses a number of such cases, including Shawandawa from the Brazilian Amazon, Quechua in the South American Andes, the East Indian communities of South Africa, Khmer in Philadelphia, Welsh, Maori, Turkish in the UK, and Native Californian languages. At a time when phrases like "endangered languages" and "linguicism" are invoked to describe the plight of the world's vanishing linguistic resources in their encounter with the phenomenal growth of world languages such as English, the cases reviewed here provide consistent and compelling evidence that language policy and language education serve as vehicles for promoting the vitality, versatility, and stability of these languages, and ultimately promote the rights of their speakers to participate in the global community on and IN their own terms.
\end{abstract}

\section{Keywords}

endangered languages, immigrant languages, indigenous languages, language revitalization, linguicism

Disciplines

Education | Linguistics | Other Languages, Societies, and Cultures 


\title{
Language policy, language education, language rights: Indigenous, immigrant, and international perspectives
}

\author{
NA N CY H. HORNBERGER \\ Graduate School of Education \\ University of Pennsylvania \\ Philadelphia, PA 19104-6216 \\ nancyh@gse.upenn.edu
}

\section{A B S T R ACT}

Indigenous languages are under siege, not only in the US but around the world - in danger of disappearing because they are not being transmitted to the next generation. Immigrants and their languages worldwide are similarly subjected to seemingly irresistible social, political, and economic pressures. This article discusses a number of such cases, including Shawandawa from the Brazilian Amazon, Quechua in the South American Andes, the East Indian communities of South Africa, Khmer in Philadelphia, Welsh, Maori, Turkish in the UK, and Native Californian languages. At a time when phrases like "endangered languages" and "linguicism" are invoked to describe the plight of the world's vanishing linguistic resources in their encounter with the phenomenal growth of world languages such as English, the cases reviewed here provide consistent and compelling evidence that language policy and language education serve as vehicles for promoting the vitality, versatility, and stability of these languages, and ultimately promote the rights of their speakers to participate in the global community on and IN their own terms. (Endangered languages, immigrant languages, indigenous languages, language revitalization, linguicism)*

Indigenous and immigrant languages are under attack, around the world, subjected to seemingly irresistible social, political, and economic pressures. Yet, although scholars use phrases like "endangered languages" (Hale et al. 1992) and "linguicism" (Phillipson 1992) to describe this situation, there is also accumulating evidence that language policy and language education can serve as vehicles for promoting the vitality, versatility, and stability of these languages. This article considers the role of policy and education in language rights and revitalization efforts around the world, taking up cases of indigenous languages (and their vitality), immigrant languages (and their versatility), and international language rights (and their stability) in turn. Each section begins with a short illustrative vignette drawn from my own field experience in the Brazilian Amazon, post-apartheid South Africa, and the Welsh Isle of Anglesey. The final section argues that a "language as resource" perspective (Ruiz 1984) is fundamental to 
the vision of language policy, language education, and language rights presented here - not a static or conflict-free vision of language as resource, but a negotiative, transformative one.

We begin with a vignette from my field experience in Amazonian Brazil: ${ }^{1}$

Every year since 1983, an indigenous teacher education course sponsored by the Comissão Pró-Indio (CPI) of Acre State has been held during the summer months (January-March) in the Amazonian rainforest of Brazil. The 1997 session was attended by some 25 professores indios 'indigenous teachers', representing eight different ethnic groups whose languages are in varying stages of vitality, from those with about 150 speakers to those with several thousand. ${ }^{2}$

One of the striking features of the course is that the professores indios are simultaneously learners and teachers-in-formation; i.e., they are simultaneously learning the school curriculum themselves for the first time, while also preparing themselves to return to their aldeias, or communities, to teach it. Another feature of the course is the emphasis on reflexive practice, epitomized in the keeping of class diaries during the school year, a practice which some of the professores indios have employed since $1983 .^{3} \mathrm{~A}$ third striking feature is the clear "language as resource" orientation, used here in Ruiz's sense. ${ }^{4}$ This orientation in the CPI course means not only that the indigenous languages are encouraged and used as medium and subject of instruction, in both the course and the schools, but also that the professores indios encourage and exchange among themselves across their different languages. One activity of the course in which all three of these features converge is the professores indios' authorship of teaching materials in the indigenous languages that reflect indigenous culture, history, and artistic expression; these materials serve as documentation of the professores' own learning while also serving as a teaching resource for their own classrooms.

The 1997 session inaugurated a new curricular area, "Introduction to research". For this area, one group of professores was learning to write proposals to gain funding for research and/or for community development. The most popular topic for proposals proved to be projects of linguistic or cultural revitalization; and among those who developed a proposal along those lines was Antônio Arara, a Shawandawa. In the introductory part of his proposal, Antônio describes the rapid diminution of his language - noting that as a result of many years of contact and conflict with white people, the Shawandawa now number only $196 ;^{5}$ there are only six native speakers of the language, all over the age of 60 . He goes on to recount that beginning in 1990, he has been involved with the CPI staff in linguistic research, and that in 1996 they produced the first primer in Shawandawa; although still incomplete, it is already yielding good 
results with the schoolchildren. His proposal is to do more tape-recording, writing, and publishing in Shawandawa, so that the next generation can be taught the language. In introducing this strategy in the face of the dismal picture of language loss with which he opens his proposal, Antônio asserts optimistically: Temos uma saida! 'There is a way out!' $(1 / 23 / 97)$

Shawandawa, also called Arara, is one of many indigenous languages around the world in danger of disappearing because they are not being transmitted to the next generation. The plight of endangered languages is considered by many to be a crisis. Krauss (1992:7) estimated that as few as 600 of the estimated 6,000 languages on Earth will remain secure through the next century. Although we lack an accurate assessment of the situation of endangered languages in most areas of the world (Grenoble \& Whaley 1996:210), we have approximate figures for enough cases to make the point quite convincingly. For example, of the 175 indigenous languages still extant in the United States, only 20 are being transmitted as child languages (Krauss 1996, as cited by McCarty 1996). In the state of California, which bears the dubious distinction of having more endangered languages than any other part of North America, of approximately 100 Indian languages spoken at the time Europeans arrived, there are today only 50 still spoken, most only by elders; and virtually $100 \%$ of California's indigenous languages are no longer learned by children (Hinton 1994).

Nor is this only an American problem. Indigenous languages around the world are undergoing similar pressure. For example, a recent paper by Brenzinger identified 16 languages in Ethiopia confronting the imminent possibility of extinction (Grenoble \& Whaley 1996:211; see also Brenzinger 1992). Nelde et al. 1996 consider the current situation of $\mathbf{4 8}$ minority language groups in the European Union, and in particular "their potential for production and reproduction, and the difficulties which they encounter in doing so." The report looks at the "implications of the more general process of political and economic restructuring within the EU for minority language groups," and argues that given "the shift in thinking about the value of diversity for economic development and European integration, attention must be given to sustaining the existing pool of divesrsity within the EU" (Nelde et al. 1996, Executive Summary).

Over the past decade, endangered languages have received increasing scholarly attention, in publications (e.g. Hale et al. 1992) and at conferences, e.g. the November 1994 and May 1995 Flagstaff Roundtables on Stabilizing Indigenous Languages (Cantoni 1996); a February 1995 conference held at Dartmouth (Grenoble \& Whaley 1996); and an October 1996 conference on Endangered Languages, Endangered Knowledge, Endangered Environments, held in Berkeley. The year 1996 also saw the founding of a non-profit, non-governmental international organization, Terralingua (http://cougar.ucdavis.edu/nas/terralin/ home.html) devoted to preserving the world's linguistic diversity and to investigating parallels and links between biological and cultural diversity. 
Parallels are drawn between endangered languages and endangered species; in each case, the endangered ones, as Crawford writes (1994:5), "fall victim to predators, changing environments, or more successful competitors," are encroached on by "modern cultures abetted by new technologies," and are threatened by "destruction of lands and livelihoods; the spread of consumerism, individualism, and other Western values; pressures for assimilation into dominant cultures; and conscious policies of repression." Yet, as Grenoble \& Whaley assert, despite a recognition of some "commonality to the general circumstances that bring about language endangerment, ... [it is] regionally specific, or even community-specific, factors [that] dictate the ultimate effect of these circumstances" (1996:211). Among the latter, they suggest, is the factor of how a particular language community may react when confronted with imminent language loss - specifically, whether or not the community can or will mobilize resources to counteract the loss.

Fishman (1991:112) calls such activities "Reversing language shift" (RLS), and he argues that RLS cannot be successful without intergenerational language transmission. "Nothing can substitute for the rebuilding of society at the level of ... everyday, informal life." In a recent collection of essays (Hornberger 1996a), paired or co-authored contributions by scholars working with members or native speakers of various indigenous language communities in North, Meso- and South America describe efforts to maintain and revitalize their languages through the use and development of various literacies. The volume's concluding essay suggests that the striking characteristic of the efforts described is their bottom-up nature. In the curriculum development work with the Yup'ik of Alaska described by Jerry Lipka, Esther Ilutsik, and Nastasia Wahlberg; the book publication project of Oaxaca, Mexico, described by Russell Bernard, Jesús Salinas, and Josefa Gonzalez; the Guaraní literacy campaign in Bolivia described by Luis Enrique López; and many more, it is "the involvement and initiative of the indigenous communities themselves that ... provide the impetus and sustenance for language planning efforts" (357). Antônio Arara's rallying statement above, Temos uma saida, is another example of that kind of bottom-up response. It is indicative of the incredible initiative, energy, and enthusiasm indigenous people can put into revitalization efforts when they feel their language or culture are threatened; these efforts are most often based around literacy and education.

Arara's statement is also indirect evidence of the role that national language and education policy can have in encouraging or dampening such enthusiasm. In the Brazilian case, the Constitution of 1988 marked a significant turning point in policy for the indigenous populations. That constitution recognizes, for the first time, the Indians' social organization, customs, languages, beliefs, and traditions, and their native rights to the lands that they have traditionally occupied (Brazil 1996, Chap. VIII, Art. 231); the constitution also ensures that education in indigenous communities will make use of their native languages and learning processes (Chap. III, Art. 210). In 1993 the Brazilian Ministry of Education appointed a Committee on Indigenous Education, which serves in an advisory capacity to 
the Ministry and has formulated a set of policy guidelines for indigenous education (Brazil 1994b). The revitalization efforts of Antônio Arara and the other professores índios, in conjunction with the Comissão Pró-Indio, occur in the context of this political opening toward recognition of the Indians and of their rights to their languages and to education in their languages. ${ }^{6}$

Such a political opening was also the impetus for one of the first major indigenous bilingual education initiatives in South America, the Puno Bilingual Education Project. In that case, it was the 1975 recognition of Quechua as an official language of Peru that paved the way for the Puno bilingual education project. This served approximately $4 \%$ of the school-aged Quechua- and Aymara-speaking population of the Department of Puno throughout the 1980s; it developed the first complete set of bilingual primary education materials in an indigenous language in Latin America; and it has served as a model, inspiration, and resource for bilingual education initiatives in Latin America in the 1990s (López 1996a, Hornberger 1988a, Hornberger \& López 1998).

One such 1990s initiative is that of Bolivia,where indigenous-language speakers make up $63 \%$ of the population, and where major language and education policies are being introduced that have significant consequences for indigenous language maintenance and revitalization. The Bolivian National Education Reform of 1994 envisions a comprehensive transformation of the educational system, including the introduction of all thirty of Bolivia's indigenous languages alongside Spanish as subjects and media of instruction in all Bolivian schools. Teaching and learning modules are being developed by native speakers for all the languages. Those for Quechua and Aymara draw on the experience of the Puno and other experimental bilingual education projects carried out in Bolivia, Peru, and Ecuador in the 1970s and 1980s, while those for Guarani draw on the experience gained in a successful participatory literacy campaign carried out in 1992-93 (López 1996b). Work in the other indigenous languages is at present comprised largely of orthographic and lexical development, carried out through a partnership approach between young, informed speakers of the languages and academic specialists appointed by the indigenous communities to work on their languages; this work had originally been slated to start in the year 2002, with the second phase of the Bolivian Reform, but political pressure from the Amazonian and East Andean indigenous groups advanced it to the first phase. The Bolivian Education Reform, undertaken in conjunction with the Popular Participation Process also launched in 1994, constitutes the institutional cement for the construction of a new Bolivian state in which pluralism is seen as a resource and not a problem (Lopez 1995:87).

Post-apartheid South Africa's new constitution (Act No. 200 of 1993) also embraces language as a basic human right, and multilingualism as a national resource - diverging from its former "language as problem" orientation (cf. Chick 1996). The Constitution raises nine major African languages to national official status alongside English and Afrikaans. ${ }^{7}$ It states that "Every 
person shall have the right to use the language of his or her choice" (Sec. 31); that "no person shall be unfairly discriminated against, directly or indirectly, on the grounds of language" (Sec. 8); that "each person has the right to instruction in the language of his or her choice where this is reasonably practicable" (Sec. 32); and that "each person, wherever practicable, shall have the right to insist that the State should communicate with him or her at national level in the official language of his or her choice and at provincial level in any provincial official language" (Sec. 3) (South Africa 1993). The Language Plan Task Group, appointed in December 1995 to advise on the development of a national language plan, is working at the level of subcommittee and national consultation (South Africa 1996). The Pan South African Language Board, mandated by the constitution and established in March 1996, is charged with responsibility for promoting multilingualism through such measures as the development and promotion of equal use of the official languages, the provision of translation services, and the promotion of respect for and development of other languages used by communities in South Africa, e.g. Indian languages and German (Chick 1996:3). Although it is only in the beginning stages, the impact of this new language policy has already begun to be felt in the schools - which are not only rapidly desegregating because of the end of apartheid, but are also confronting the opportunities and challenges of bilingual and multilingual education (PRAESA 1995).

In the US, the 1990 and 1992 Native American Languages Act declares that the US government's policy is to "preserve, protect, and promote the rights and freedom of Native Americans to use, practice, and develop Native American languages" (P.L. 101-477, Section 104[1]). McCarty (1996b) reports that "though meagerly funded, [this Act] has supported some of the boldest new initiatives in indigenous language revitalization, including language immersion camps and master-apprentice programs in which elderly speakers team with younger tribal members over months and years in natural language learning activities."

There is no question, then, that language policies with a language-as-resource orientation can and do have an impact on efforts aimed at promoting the vitality and revitalization of endangered indigenous languages. Of course, this is not to say that protecting indigenous languages is simply a matter of declaring a language policy to that effect. There is ample evidence to the contrary.

For one thing, there may be other, conflicting policies that inhibit the effect of the "language as resource" policy. After all, in the US, we have not only the Native American Languages Act, but also the proposed Language of Government Act - which, if enacted, would designate English as the official and sole permissible language of US government business, with only a few exceptions. We will return to this below.

Additional obstacles to protecting indigenous languages simply by declaring policy include the well-known gap that is nearly always present to some degree between policy and implementation, and the fact that policies may change or get 
overruled. Looking back from today's vantage point, it is clear that both these things happened in the case of the 1975 Quechua Officialization in Peru. Not only was there a lack of government follow-through in terms of budgetary and institutional support for Quechua officialization; but also, in the years subsequent to 1975 , Peruvian policy retreated somewhat from the resource orientation to a "language as right" orientation, providing attention to Quechua language maintenance but not necessarily to its development and extension (Lopez 1996a, Hornberger 1988a,b, Hornberger \& López 1998).

Finally, there is what we might call, for lack of a better term, the force of history, which may overwhelm any policy attempt. It is worth noting in this regard that, while my own dissertation research on Quechua in the early 1980s was formulated around the question of language MAINTENANCE (Hornberger 1988a), a decade later my student Kendall King formulated her dissertation research around the question of the Revitalization of Ecuadorian Quichua (King 1997). To be sure, part of this change can be attributed to different histories in Peru and Ecuador; to different language maintenance and loss trajectories in different Quechuaspeaking communities throughout the Andes (cf. Grenoble \& Whaley 1996 on regional specific and community specific circumstances); and perhaps even to the different theoretical or experiential outlooks of different researchers. At least part of the change, however, is also attributable to a growing threat to even such a large indigenous language as Quechua, with its estimated 10 million or more speakers. We will return to this point below.

LANGUAGE EDUCATION, IMMIGRANT LANGUAGES,

AND VERSATILITY

A vignette from post-apartheid South Africa:

South Africa's new Constitution elevates nine African languages to national official status alongside English and Afrikaans, while also providing for the promotion of respect for and development of other languages used by communities in South Africa. Among those "other languages" are the languages of India. Approximately $40 \%$ of the population of Durban is of Indian and Pakistani origin, said to be one of the largest Indian populations outside of South Asia, and constituting a presence dating from 1860 when the first indentured laborers from India arrived to work on the sugar plantations. Under apartheid, Indians formerly had their own separate educational system with English as medium of instruction - surely a factor in widespread shift to English among the Indian population.

Nevertheless, Dr. Varijakshi Prabhakaran of the Department of Indian Languages at the University of Durban-Westville argues that, despite the widespread perception that Indians in South Africa all speak English and that the Indian languages have all but disappeared, there are in fact significant numbers of speakers of the Indian languages, as well as significant ongoing efforts in 
language maintenance and revitalization. In conversation with me after a talk I have just given at the University of Natal, she comments that, in her view, the Indian languages are oppressed minority languages in South Africa - the more so now that there are nine official African languages along with English and Afrikaans; and she expresses her sense of urgency that something be done about supporting these languages. (6/12/96)

Prabhakaran's plea on behalf of the immigrant Indian population, for attention and support for Indian languages in South Africa, is echoed around the world by immigrants who seek to maintain their languages in the face of seemingly irresistible social, political, and economic pressures to assimilate to the languages and cultures of their new countries. This plea is almost always matched in intensity by the complementary plea for opportunity to learn the new country's language as well. In other words, the plea of immigrants is that they ought to be enabled to learn and use the new language, but also to keep and use their own language, the "old" language, in their new country. This twin plea, an expression of immigrant bilingual versatility, is remarkably consistent around the world; yet what is equally remarkable and consistent around the world is that the immigrants' new country often seeks to force a choice for one or the other language - or worse still, ignores both pleas.

Suárez-Orozco 1996 has recently drawn attention to similarities in the immigrant experience in the US and Western Europe - similarities that set the context for the assimilatory pressures mentioned above. He notes that, in both cases, there are three primary causes of recent increases in immigration, and in particular in undocumented immigration: (a) policies that aim at recruiting foreign workers to feed a voracious appetite for inexpensive labor; (b) a reliance by some sectors of the market on foreign workers to do the jobs nobody else wants to do, even with high unemployment among native workers; and (c) stunning global economic and political transformations (e.g. NAFTA in the US; political upheaval and the spread of ethno-nationalistic conflicts in Europe).

Suárez-Orozco goes on to note that, in both Western Europe and the US, similar and largely unfounded concerns characterize what he observes as a growing anti-immigrant sentiment, namely: (i) concern that there are just too many new arrivals; (ii) the belief that limits on immigration have largely failed to contain the undocumented immigrants and asylum seekers; (iii) anxiety about the economic consequences of immigration; (iv) the explosive charge that immigrants contribute disproportionately to problems of crime; (v) a general anxiety that new arrivals are transforming the demographic landscape; and (vi) a pervasive anxiety that new immigrants are not assimilating easily.

It is this kind of xenophobia that leads to policies such as California's Propositions 187 and 227, adopted in 1994 and 1998, and the proposed Language in Government Act, currently before the US Congress. ${ }^{8}$ This act, which would require that English be used by "all employees and officials of the Government of 
the United States while performing official business", has been characterized by Senator Paul Simon as a "not very subtle symbolic attack" on Hispanic and Asian Americans - a reading reinforced by proposed amendments that would exempt "the use of [both] indigenous and foreign languages in education" from this English-only mandate (Crawford 1996).

Richard Ruiz (1996) points out that "movements toward the officialization of English in the United States are consistent with the tendency in large multinational states to promote a transethnified public culture." He differentiates "transethnification" from assimilation, in that in transethnification, "It is not necessary to lose one's ethnicity to be useful to the state, ... nor is it necessary ... that one's attachment to the state have any sentimental aspect (in Kelman's [1971] sense of historicity and authenticity)." In the US, Ruiz argues, languages other than English are "perfectly acceptable ... [but only] as long as they are mediated through individuals and not communities; [however,] if they are community languages, they should be confined to the private sector and not make demands for public subsidy; [and] if there is to be public subsidy, their use should be for the common public good, and not signal competing allegiances."

In a language ideology built on the promotion of transethnification, instrumentalism, and nationism, as Ruiz suggests that US and other multinational states' language ideologies are, it is difficult to find room for state-supported programs of language education that would promote the full use and development of two or more languages in school, and that would lead to the kind of bilingual/biliterate/ bicultural versatility encapsulated in the immigrants' twin plea to learn the new and keep the old. The case of Israel offers an example of a state that has in the past been characterized by such a monolingual ideology, geared toward the revitalization of Hebrew and bolstered by a series of myths and assumptions; however, new multilingual language education policies of 1995 and 1996 offer promise for indigenous and immigrant languages including Arabic, the Jewish heritage languages, and more recent immigrant languages such as Russian and Amharic (Shohamy 1994, Spolsky \& Shohamy 1998). My own work, along with my reading of others' work on language and education policy and practice for immigrant (and other) language minorities in the US and elsewhere, has led me to formulate two principles that support such multilingual ideologies and policies.

The first principle, drawn as an implication from the continua model of biliteracy (Hornberger 1989), is that the more the contexts of their learning allow bilingual/biliterate learners to draw on all points of the continua of biliteracy, the greater are the chances for their full biliterate development. That is, the contexts of their learning must allow learners to draw on oral-to-literate, monolingual-tobilingual, and micro-to-macro contexts; to use productive and receptive, oral and written, and L1 and L2 skills; and to receive both simultaneous and successive exposures, with attention to both similar and dissimilar aspects of language structure, and to convergent and divergent aspects of language scripts (Hornberger 1990, 1992). 
In a multi-year ethnographic dissertation study of women and girls in several Cambodian refugee families in Philadelphia, Ellen Skilton Sylvester (1997:vii) notes: "The challenges many [Cambodian] women and girls face in learning to read and write English are often seen in relation to short schooling histories in Cambodia, differences between Khmer and English, and little exposure to reading and writing in their first language." Although her study addresses these issues, Skilton Sylvester places the onus of responsibility on "educational policies and practices [that] often treat the Cambodian students' native language as a problem rather than a resource, and provide few opportunities for these students to practice and learn the literacy skills needed to become 'literate insiders' in the United States" (1997:vii).

Using the continua model of biliteracy as a "tool for uncovering the aspects of literacy that influence participation in educational programs by Cambodian women and girls," Skilton Sylvester suggests that - in addition to the continua of biliterate contexts, development, and media - the continua of CONTENT, the meaning or "inside" of literacy (as compared to media, the structure or "outside" of literacy), constitute an additional key dimension, particularly so for an understanding of how it is that these Cambodian women and girls remain literate "outsiders" rather than becoming "insiders" (1997:187). By content, Skilton Sylvester refers to "what is taught through and about reading and writing as well as what is read and written" (1997:242), and she defines it in terms of majority-minority, literaryvernacular, and parts-whole continua. For these Cambodian women and girls, being "outsiders" has to do with whether, and to what degree, literacy contents to which they are introduced in their classes include serious attention to Asian voices and experience (i.e. a range of minority as well as majority contents); to the kinds of literacies they practice in their daily lives, e.g. the reading of romances; to the writing of letters, stories, and plays (i.e. a range of vernacular as well as literary contents); and to reading and constructing whole texts, as well as performing rote memorization, drills, and fill-in-the-blank exercises (i.e. a range of parts-towhole language contents).

Skilton Sylvester applies micro-level understandings of the meanings and uses of literacy among these Cambodian women and girls to the analysis and critique of macro-level language and education policies for language minorities in schools and adult education classes. She shows how "current practices often leave Cambodian women and girls 'in-between,' pulled in two directions by the home and the classroom"; and she points to "a different possible kind of 'in-between'" where schools and adult education programs would be " 'in-between' sites that value and respond to learners' daily lives AND teach what they need to know to become insiders in the United States" (1997:vii).

What she is talking about is exactly the kind of support for bilingual/biliterate/ bicultural versatility that is called for in pleas like Varija Prabhakaran's. With regard to mother-tongue literacy in the Cambodian community of Philadelphia, there is telling evidence that an interest in preserving Cambodian language and 
culture does not preclude the learning of English or acculturation to American ways: quite the contrary. It is precisely the individuals who practice Cambodian literacy, and who have a clear sense of specific functions for Khmer literacy - as an aid in learning English, as a skill for employment, as a vehicle to preserve Cambodian language and culture in a new land, or as an essential for going back to Cambodia to help people there - who also work hard to learn English, express a general appreciation for all languages, seek to negotiate a way of life that harmonizes their old and new cultures, and reach out to improve intercultural communication between Cambodians and Americans (Hornberger 1996b:83). This kind of versatility is essential if immigrants and their languages are not only to survive but also to thrive and contribute in their new land.

The second principle with regard to educational policy and practice for immigrant (and other) language minority learners is that the specific characteristics of the optimal contexts for their learning can be defined only in each specific circumstance or case; there is no one "program" - or even three programs, or ten, or twenty - that will necessarily provide the best learning context for all biliterate learners.

To be sure, there is accumulating consensus, in both research and practice, that enrichment models of bilingual education - those that "aim toward not only maintenance but development and extension of the minority languages, [toward] cultural pluralism, and [toward] an integrated national society based on autonomy of cultural groups" (Hornberger 1991:222) - offer much potential for both majority and minority learners' academic success. Canadian French immersion programs are one example of such a model; two-way bilingual education is another. But there are certainly other program types that could embody an enrichment model of bilingual education, whose "primary identifying characteristic is that the program structure incorporate a recognition that the minority language is not only a right of its speakers but a potential resource for majority language speakers" (Homberger 1991:226).

Nevertheless, the specifics of how a program actually incorporates that recognition will vary greatly depending on context; and we need many more indepth studies and descriptions of such programs before we can begin to understand what works, what doesn't work, and why. One two-way bilingual education program for which we have a detailed description is the Oyster School in Washington, DC, one of the oldest two-way programs in the US. In the early 1990s, at the time of Rebecca Freeman's ethnographic/discourse-analytic study, the Oyster School's population was $58 \%$ Hispanic, $26 \%$ white, $12 \%$ black, and $4 \%$ Asian, representing more than 25 countries (Freeman 1996:558). The school's language plan, then as now, provided for instruction in Spanish and English for children speaking both majority and minority languages. Freeman began by looking at patterns of language use in this bilingual school, and she ended by discovering that curriculum organization, pedagogy, and social relations were shaped by a larger underlying identity plan. 
Freeman's original intention was to study the two-way bilingual education language plan by triangulating classroom observations, the school's bilingual education policy, and conversations with principals, teachers, and students of the school. However, she began to find that there was not in fact strictly equal bilingualism in the school: Codeswitching to English in Spanish class was common, but not the reverse; there was district-wide testing in English, but not in Spanish; and the English-dominant students were not as competently bilingual in Spanish as the Spanish-dominant were in English. At that point, Freeman began a more open-ended search for "what was going on." What she found was that the success of the program resulted not so much from the school's language plan, but rather from its underlying identity plan, the school community's "attempt to provide the students not only with the ability to speak a second language, but in the case of the minority students, techniques for asserting their right to speak and to be heard in a society that, at least in the Oyster School construction, regularly refuses minority populations such rights" (Freeman 1993:107).

LANGUAGE RIGHTS, INTERNATIONAL PERSPECTIVES,

AND STABILITY

Another vignette:

Caernarvon, in North Wales on the Isle of Anglesey, is famous not only as the site of the castle where the Prince of Wales is traditionally crowned (an English, not a Welsh, event), but also as the place in the world where the most Welsh is spoken. Caernarvon is also the headquarters for CEFN, a Welsh nonparty citizens' movement which seeks equality of citizenship and equality for Welsh people as a nation and for the Welsh language. Eleri Carrog, founder, tells how the organization grew out of a 1985 nationwide petition movement to combat the misuse of the Race Relations Act, ${ }^{9}$ and to support the right of employers to recruit bilingual speakers to give service in a bilingual community. That petition drive was the original impetus for a movement that has grown far beyond the founder's expectations, with CEFN becoming an unofficial legal aid system for those wishing to fight authority to establish language rights. CEFN, with others engaged in the campaign for Welsh language rights, has met some success with the 1993 passage of the Welsh Language Act. (9/ 3/96)

It is not only Welsh speakers who have become activists for the right to use their own language. Language rights, or linguistic human rights, have taken on increasing urgency worldwide in the light of the twin threat posed by the loss of a vast proportion of the world's linguistic resources - the endangered languages and by the growth of world languages like English.

This year marks 50 years since the Universal Declaration of Human Rights was adopted unanimously by the United Nations General Assembly in 1948. 
Within the last decade, two UNESCO-supported conferences (Recife, October 1987, and Paris, April 1989) have called for a Universal Declaration of Language Rights that would "ensure the right to use the mother tongue in official situations, and to learn well both the mother tongue and the official language (or one of them) of the country of residence" (Phillipson 1992:96). Since 1985, the Working Group on Indigenous Populations of the UN Commission on Human Rights has been developing a draft Universal Declaration on Indigenous Rights, which includes, among 28 rights of indigenous peoples, "the right to maintain and use their own languages, including for administrative, judicial, and other relevant purposes; [and] the right to all forms of education, including in particular the right of children to have access to education in their own languages, and to establish, structure, conduct, and control their own educational systems and institutions" (Alfredsson 1989:258).

In sum, these declarations call for the right to education in one's own language, and the right to a significant degree of control over the educational process as it affects one's children. Stephen May argues for both these rights for indigenous minorities, and he offers the case of Maori education in Aotearoa/New Zealand as an example where such rights have led to developments in which "a long and debilitating history of colonization and marginalization for Maori is being contested, and Maori language and culture [is being] reasserted" (May 1996:154). In a situation where Maori language was "all but ... banned from the precincts of the schools" from the turn of the twentieth century (1996:157), and was in rapid decline especially after World War II (1996:158), May notes, "Two recent educational developments have begun to halt the process of language loss for Maori: first, the establishment of bilingual schools in the late 1970s; and second, and more significantly, the emergence of alternative Maori-medium (immersion) schools - initiated and administered by Maori - during the course of the 1980s" (1996:160).

Alternative, Maori-controlled, Maori-medium education began at the preschool level in 1982 with the Kohanga Reo 'Language Nests'; it has grown to a movement including not only primary schooling in the Kura Kaupapa Maori 'Maori philosophy schools', but also secondary and tertiary-level institutions. Furthermore, since 1990 both Kohanga Reo and Kura Kaupapa Maori have been incorporated into the state educational system as recognized (and state-funded) alternative education options - a situation not without some contradictions with respect to the notion of relative autonomy that has been so fundamental to the movement (May 1996:164). As of 1991, 1\% of Maori primary school students were enrolled in Kura Kaupapa Maori; as of 1993, 49.2\% of Maori children enrolled in pre-school were at a Kohanga Reo. Comparing the case of Maori language revitalization to the Hebrew case, Spolsky suggests that, just as in the Hebrew case ideology played a crucial role in the success of language revitalization efforts, so too there are signs of the strength of ideology in the Maori case. Specifically, the Maori efforts (a) have been community-based, even shying away from government; (b) they are concerned not just with language, but with main- 
taining ethnic identity; and (c) they opt out from mainstream linguistic and cultural ideologies (Spolsky 1995).

McCarty et al. 1994 tell of similar success stories in American Indian/Alaska Native education, where local knowledge has successfully become a genuine foundation for indigenous schooling, as a result of decade-long, collaborative efforts by native speakers and non-native educators. In a concluding essay to that volume (Hornberger 1994), I suggest that the enabling conditions for such sustained and lasting improvements in indigenous schooling, as gleaned from the Native American experience as well as the case of the Puno bilingual education project I studied, include the following: a vital native language valued by the community; versatile bilingual/bicultural/biliterate personnel who take the lead in effecting change in their schools; and long-term stability of the change site stability of site personnel, governance, and funding (Hornberger 1994:62)

\section{"LANGUAGE AS RESOURCE" POLICY / LANGUAGE POLICY AS A RESOURCE}

The language as resource orientation in language planning, as first discussed by Ruiz 1984, is fundamental to the vision of language policy, language education, and language rights presented here; but in concluding, I should emphasize that it is not an uncomplicated, conflict-free vision of "language as resource" that I have in mind.

Language policy with a "language as resource" orientation can and does have an impact on efforts aimed at promoting the vitality and revitalization of endangered indigenous languages, and it is in this sense that we can speak of language policy itself as a resource. It is also true, however, that the force of history may overwhelm ANY policy attempt, even in the case of such a large indigenous language as Quechua.

Aodán Mac Póilin, writing about the Irish Language Movement in Northern Ireland (1996), has talked about this in terms of linguistic momentum, i.e. "the forces which ensure that a language is used in society and passed on from one generation to the next." He notes that the same linguistic momentum "which allowed Irish to survive against enormous pressures in pockets of the country is now working in the other direction, in favor of English, and is, in spite of the best efforts of the revivalists, effectively inhibiting the development of Irish as a community language outside the Gaeltacht."

After all, it is not the number of speakers of a language, but their positioning in society, that determines their patterns of language use. Mac Póilin refers to the relative linguistic significance of groups of speakers, which he says "is related less to the number of speakers than to the degree to which the language is integrated into the daily life of its users; their social coherence; and most importantly if the language is to survive, the community's ability to successfully regenerate itself as a speech community" (1996:4). 
The whole notion of language minority has more to do with power than with numbers, anyway. ${ }^{10}$ However, if it is true that our language and literacy practices position us in social and power hierarchies, it is also true that they may be sites of negotiation and transformation of those hierarchies. In a recent essay on research on bilingualism among linguistic minorities, Martin-Jones notes (1992:16) that the conflict research tradition seeks to explain how and why languages come to be functionally differentiated, in terms of a social history of inequality, while the micro-interactionist research tradition sees "individuals within a bilingual community ... as actively contributing to the definition and redefinition of the symbolic value of the community's languages in daily conversational interactions."

An example of the kind of negotiative and transformative action that individuals within a bilingual community can take is the bottom-up revitalization effort mentioned earlier. Of fundamental importance here is that such revitalization efforts are not about bringing the language back, but rather about bringing it forward:

When we consider that reversing language shift entails altering not only the traditional language corpus but also how it is traditionally used, both at the micro level in terms of inter-personal discourse patterns, and at the macro level of societal distribution, the crucial importance of the involvement of speakers of the language becomes even more apparent. In a very real sense, revitalization initiatives ... are not so much about bringing a language back; but rather, bringing it forward; who better or more qualified to guide that process than the speakers of the language, who must and will be the ones taking it into the future? (Hornberger \& King 1996:440).

May also emphasizes this point when he clarifies that the movement for alternative, Maori-medium education is "neither separatist nor a simple retrenchment in the past" (1996:164); rather, he says, it revolves around a question of control, of having Maori-medium education available as a legitimate schooling choice. He reminds us that "nothing in the assertion of indigenous rights - or minority rights more generally - precludes the possibilities of cultural change and adaptation" (1996:164).

Furthermore, it is not only members of language minority communities but also language education professionals who can be active contributors to negotiative, transformative processes of language revitalization, language maintenance, or indeed language shift. There is increasing recognition in our field of the role of language education professionals as language policy makers, whether they are classroom practitioners, program developers, materials and textbook writers, administrators, consultants, or academics (cf. Hornberger \& Ricento 1996). McCarty has gone so far as to argue (1996) that "while schools cannot in themselves 'save' threatened indigenous languages, they and their personnel must be prominent in efforts to maintain and revitalize those languages." In this regard, and again from a "language as resource" perspective, key considerations for the education of 
indigenous, immigrant, and other language minorities are bilingual/bicultural/ biliterate versatility, the continua of biliteracy, and enrichment-model bilingual education.

Once again, though, I do not mean to suggest that the implementation of a "language as resource" perspective offers a conflict-free solution. In our finite world, the recognition and incorporation of multiple languages within any single educational system is bound occasionally to bring the language rights and needs of one group into conflict with those of another, not to mention the long-standing conflict between language and content priorities in the education of language minorities. A recent dissertation by Angela Creese (1997) looks at the limits and successes of a UK language policy that aims to provide for the language rights and needs of bilingual children in multicultural schools through mainstreaming the children while providing them with in-class language support - an approach also familiar in the US. Using an ethnographic interpretive methodology, Creese observed and audio-recorded Turkish bilingual teachers and Anglo teachers of English as a second language as well as the subject teachers they were working with in their classrooms. She looked at the relationships the teachers formed, the roles they played in class, and the language they used in playing these out; she found that, within the constraints imposed by the educational aims and reality of current policy, the language rights of the children rarely became a priority equal to the content-based aims of secondary education. The teachers showed great versatility in forming a range of collaborative relationships (which Creese calls support, partnership, and withdrawal); but if they attempted to change the hierarchy of educational aims, they were often challenged by the children they were helping. Further, teachers who worked outside this hierarchy of aims "[were] not only in danger of working themselves out onto the periphery in terms of their own status in the school, but [could] also be seen by the children they [were] targeting as providing a deficit form of education" (1997:2). Creese concludes that "there is much more that can be done to celebrate rather than tolerate [the] diversity in British schools" (1997:322). This account is not intended to single out UK policy for criticism, but to illustrate a point that holds true for many language policies around the world: A serious commitment to provision of the rights for children to be educated in their own language requires a systemic and systematic effort, which cannot necessarily be handled by an add-on program or policy.

Language rights, then, from a "language as resource" perspective, are not a question of automatic "concession on demand", but rather of control and choice among potential alternatives, in balanced consideration of other possibilities. Elsewhere I have argued (Hornberger 1997) that it is crucial that language minorities be empowered to make choices about which languages and which literacies to promote for which purposes; and that, in making those choices, the guiding principles must be to balance the counterpoised dimensions of language rights for the mutual protection of all. Among the balances that must be struck across compet- 
ing language rights are those between tolerance-oriented and promotion-oriented rights (Kloss 1977), between individual and communal freedoms (SkutnabbKangas 1994), between freedom to use one's language and freedom from being discriminated against for doing so (Macías 1979), and between "claims to something" and "claims against someone else" (Ruiz 1984). These are difficult ethical choices, but they must be made; I am arguing here that those best qualified to make them are the language minority speakers themselves.

At a time when phrases like "endangered languages" and "linguicism" are invoked to describe the plight of the world's vanishing linguistic resources, in their encounter with the phenomenal growth of world languages such as English, I have argued here that there is also consistent and compelling evidence that language policy and language education serve as vehicles for promoting the vitality, versatility, and stability of these languages, and ultimately of the rights of their speakers to participate in the global community on, and IN, their own terms.

Leanne Hinton has reported on the 1992 Tribal Scholars Language Conference, a gathering of Native Californian language activists at Walker Creek Ranch in Marin County, one of the outcomes of which was the master-apprentice language program mentioned earlier. In conversation with L. Frank Manriquez, a Native Californian artist of Tongva and Ajachmem origins, Hinton commented on how inspiring the conference had been, even in the face of what appeared to be a hopeless situation for so many native Californian languages. To this Manriquez responded, "Yes. How can it be hopeless when there is so much hope?" (Hinton 1994:233).

\section{NOTES}

* This is a slightly revised version of a paper originally presented in March 1997 as a plenary talk at the annual conference of the American Association for Applied Linguistics in Orlando, Florida; and in April 1997 as a keynote speech at the First National Conference on Directions for Language Policy in Israel: Languages in Society and School, sponsored by the Language Policy Research Center at Bar-Ilan and Tel Aviv Universities, Israel. My thanks go especially to Mary McGroarty, AAAL '97 Program Chair, who invited and encouraged me to write the talk.

For each vignette, the date given in parentheses at the end denotes that I was a participant/ observer of the incident described, on that date.

${ }^{2}$ The ethnic groups represented in the 1997 course are, in order of total estimated number of speakers from greatest to smallest: Asheninca or Kampa, with a population of only 560 in Brazil, but 55,000 in Peru; Kaxinawá, with 2,700 in Brazil and another 1,200 in Peru; Apurinã, 2,800; Jaminawá, 370 in Brazil and 600 in Peru; Katukina, 650; Arara or Shawandawa, 300; Yawanawá, 230; and Manchineri, 152 (Brazil 1994a).

${ }^{3}$ See Monte 1996 for a description and analysis of the diaries; and see Cavalcanti 1996 for insight into the reflexive nature of the cross-cultural interaction between the professores indios and one of the professores brancos 'white teachers' who provide instruction in the course.

${ }^{4}$ Here and throughout this paper, I and the authors I cite follow Ruiz 1984 in referring to "language as resource", "language as right", and "language as problem" orientations.

${ }^{5}$ His number differs somewhat from the figures in Brazil 1994a, which lists 300 Shawandawa, all of them in Acre State.

${ }^{6}$ The eight ethnic groups represented at the CPI course are only a few of the 206 indigenous peoples of Brazil (see Brazil 1994a). 
${ }^{7}$ The nine languages are Ndebele, Northern Sotho, Southern Sotho, Swati, Tsonga, Tswana, Venda, Xhosa, and Zulu. All these already had regional official status in various parts of South Africa.

${ }^{8}$ Approved as H.R. 123 on 1 August 1996 and introduced in the Senate as S. 356 in the 104th Congress (1995-96), this bill was reintroduced in the 105th Congress as H.R. 123 on 7 January 1997 and as S. 323 on 13 February, but so far "appears to lack influential backers" (Crawford 1997). The text of the version passed by the House in 1996 can be found on the World Wide Web at http:// thomas.loc.gov/cgi-bin/query/4?c104:/temp/ c104t60x::.

${ }^{9}$ The misuse of the Race Relations Act was in the Jones and Doyle case (Carrog 1991) where the Race Relations Board had successfully supported English-language applicants against Gwynedd County Council, who wished to appoint a bilingual assistant in a Welsh old people's home.

${ }^{10}$ May (1996:165) puts it this way: "Although the term 'minorities' tends to draw attention to numerical size, its more important reference is to groups with few rights and privileges (see Byram, 1986; Tollefson, 1991)." Nelde et al. (1996:1) note that "the concept of minority by reference to language groups does not refer to empirical measures, but rather, to issues of power."

\section{REFERENCES}

Alfredsson, Gudmundur (1989). International discussion of the concerns of indigenous peoples. Current Anthropology 30:255-59.

Brazil (1994a). Banco de dados do Programa Povos Indígenas no Brasil. São Paulo, Brazil: CEDI/ Instituto Socioambiental, November.

Brazil (1994b). Diretrizes para a política nacional de educação escolar indígena. (Cadernos educação básica, Série institucional, vol. 2.) Brasilia: Ministerio da Educação e do Desporto (MEC)/ SEF/DPEF.

Brazil (1996). Constituição da República Federativa do Brasil (CF/88). São Paulo: Editora Revista dos Tribunais.

Brenzinger, Matthias (1992), ed. Language death: Factual and theoretical explorations with special reference to East Africa. Berlin: Mouton de Gruyter.

Byram, Michael (1986). Schools in ethnolinguistic minorities. Journal of Multilingual and Multicul. tural Development 7:97-106.

Cantoni, Gina (1996), ed. Stabilizing indigenous languages. Flagstaff, AZ: Northern Arizona University Center for Excellence in Education.

Carrog, Ederi (1991). The unconquered language - a nation's will to live. Western Mail (UK), 25 July.

Cavalcanti, Marilda (1996). An indigenous teacher education course in Brazil: Cross-cultural interaction, voices and social representation. Paper presented at University of Pennsylvania Graduate School of Education, Language in Education Division Colloquium, November.

Chick, Keith (1996). Language policy in the Faculty of Humanities: Discussion Document. (Unpublished manuscript.) Durban, South Africa: University of Natal, June.

Crawford, James (1994). Endangered Native American languages: What is to be done and why? Journal of Navajo Education 11:3.3-11.

- (1996). Update on English-only legislation, IV, 9 March. http://ourworld.compuserve.com/ homepages/jwcrawford.

(1997). Update on English-only legislation, IX, 4 March.

Creese, Angela (1997). Partnership teaching in mainstream British secondary school classrooms: A language policy for bilingual students. Dissertation, University of Pennsylvania.

Fishman, Joshua A. (1991). Reversing language shift: Theoretical and empirical foundations of as. sistance to threatened languages. Philadelphia: Multilingual Matters.

Freeman, Rebecca D. (1993). Language planning and identity planning for social change: Gaining the ability and the right to participate. Dissertation, Georgetown University.

- (1996). Dual-language planning at Oyster Bilingual School: "It's much more than language." TESOL Quarterly 30:557-82.

Grenoble, Lenore A., \& Whaley, Lindsay J. (1996). Endangered languages: Current issues and future prospects. International Journal of the Sociology of Language 118:209-23.

Hale, Ken, et al. (1992). Endangered languages. Language 68:1-42.

Hinton, Leanne (1994). Flutes of fire: Essays on California Indian languages. Berkeley: Heyday. 
Hornberger, Nancy H. (1988a). Bilingual education and language maintenance: $A$ southern Peruvian Quechua case. Berlin: Mouton de Gruyter.

(1988b). Language planning orientations and bilingual education in Peru. Language Problems and Language Planning 12:14-29.

(1989). Continua of biliteracy. Review of Educational Research 59:271-96.

29.

(1990). Creating successful contexts for bilingual literacy. Teachers College Record 92:212-

(1991). Extending enrichment bilingual education: Revisiting typologies and redirecting policy. In Ofelia García (ed.), Bilingual education: Focusschrift in honor of Joshua A. Fishman on the occasion of his 65th birthday, 215-34. Philadelphia: Benjamins.

(1992). Biliteracy contexts, continua, and contrasts: Policy and curriculum for Cambodian and Puerto Rican students in Philadelphia. Education and Urban Society 24:196-211.

(1994). Synthesis and discussion - vitality, versatility, stability: Conditions for collaborative change. Journal of American Indian Education 33:3.60-63.

(1996a), ed. Indigenous literacies in the Americas: Language planning from the bottom up.

Berlin: Mouton de Gruyter.

(1996b). Mother tongue literacy in the Cambodian community of Philadelphia. International Journal of the Sociology of Language 119:69-86.

(1997). Literacy, language maintenance, and linguistic human rights: Three telling cases. International Journal of the Sociology of Language 127:87-103.

- 2 K King, Kendall A. (1996). Language revitalisation in the Andes: Can the schools reverse language shift? Journal of Multilingual and Multicultural Development 17:427-41.

— \& López, Luis Enrique (1998). Policy, possibility, and paradox: Indigenous multilingualism and education in Peru and Bolivia. In Jasone Cenoz \& Fred Genesee (eds.), Beyond bilingualism: Multilingualism and multilingual education, to appear. Clevedon, UK: Multilingual Matters.

- \& Ricento, Thomas (1996), eds. Language planning and policy and the English language teaching profession. Special issue of the TESOL Quarterly 30:3.

Kelman, Herbert C. (1971). Language as an aid and barrier to involvement to the national system. In Joan Rubin \& Bjorn Jernudd (eds.), Can language be planned? 21-51. Honolulu: University Press of Hawaii.

King, Kendall A. (1997). Language revitalization in the Andes: Quichua use, instruction, and identity in Saraguro, Ecuador. Dissertation, University of Pennsylvania.

Kloss, Heinz (1977). The American bilingual tradition. Rowley, MA: Newbury.

Krauss, Michael (1992). The world's languages in crisis. Language 68:4-10.

(1996). Status of Native American language endangerment. In Gina Cantoni (ed.), Stabilizing indigenous languages, 16-21. Flagstaff, AZ: Northern Arizona University.

López, Luis Enrique (1995). La educación en áreas indigenas de América Latina: Apreciaciones comparativas desde la educación bilingüe intercultural. Guatemala: Centro de Estudios de la Cultura Maya.

(1996a). Donde el zapato aprieta: Tendencias y desafíos de la educación bilingüe en el Perú. Revista Andina 14:295-342.

(1996b). To Guaranize: A verb actively conjugated by the Bolivian Guaranis. In Hornberger 1996a:321-53.

Mac Póilin, Aodán (1996). Aspects of the Irish language movement in Northern Ireland. Paper presented at the Canadian Association for Irish Studies, University of Prince Edward Island, June.

Macías, Reynaldo (1979). Language choice and human rights in the United States. In James Alatis (ed.), Georgetown University Round Table on Languages and Linguistics, 86-101. Washington, DC: Georgetown University Press.

Martin-Jones, Marilyn (1992). Minorities and sociolinguistics. In William Bright (ed.), Oxford International Encyclopedia of Linguistics 4:15-18. New York: Oxford University Press.

May, Stephen (1996). Indigenous language rights and education. In John Lynch et al. (eds.), Education and development: Tradition and innovation, 1:149-71. London: Cassell.

McCarty, Teresa L. (1996). Schooling, resistance, and American Indian languages. Paper presented at the Annual Meeting of the American Anthropological Association, San Francisco, November.

$\longrightarrow$, et al. (1994), eds. Local knowledge in indigenous schooling: Case studies in American Indian/ Alaska Native education. Special issue of Journal of American Indian Education, 33:2. 


\section{NANCY H. HORNBERGER}

Monte, Nietta Lindenberg (1996). Escolas da floresta: Entre o passado oral e o presente letrado. Rio de Janeiro: Multiletra.

Nelde, Peter, et al. (1996). Euromosaic: The production and reproduction of the minority language groups in the European Union. Luxembourg: Office for Official Publications of the European Communities.

Phillipson, Robert (1992). Linguistic imperialism. Oxford \& New York: Oxford University Press.

PRAESA (1995). Project proposal for the establishment of a demonstration school to explore multilingual teaching strategies and for the training of multilingual teacher specialists under South African conditions. Capetown, South Africa: University of Capetown, Project for the Study of Alternative Education in South Africa.

Ruiz, Richard (1984). Orientations in language planning. NABE Journal 8:15-34.

(1996). English officialization and transethnification in the USA. Paper presented at the Annual Meeting of the American Anthropological Association, San Francisco, November.

Shohamy, Elana (1994). Issues of language planning in Israel: Language and ideology. In Richard D. Lambert (ed.), Language planning around the world: Contexts and systemic change, 131-42. Washington, DC: National Foreign Language Center.

Skilton Sylvester, Ellen (1997). Inside, outside, and in-between: Identities, literacies and educational policies in the lives of Cambodian women and girls in Philadelphia. Dissertation, University of Pennsylvania.

Skutnabb-Kangas, Tove (1994). The politics of language standards. Paper presented at TESOL meeting, Baltimore.

South Africa (1993). South Africa's new language policy. Pretoria: Department of National Education.

(1996). State language services: Information on the Language Plan Task Group (Langtag). Cape Town: Department of Arts, Culture, Science and Technology.

Spolsky, Bernard (1995). Conditions for language revitalization: A comparison of the cases of Hebrew and Maori. Current Issues in Language and Society 2:177-201.

—_ Shohamy, Elana (1998). Language in Israeli society and education. International Journal of the Sociology of Language, to appear.

Suárez-Orozco, Marcelo (1996). Unwelcome mats. Harvard Magazine, July-August, 32-35.

Tollefson, James W. (1991). Planning language, planning inequality: Language policy in the community. London: Longman. 